Article

\title{
Actually Existing Commons: Using the Commons to Reclaim the City
}

\author{
Caroline Newton * and Roberto Rocco \\ Faculty of Architecture and the Built Environment, TU Delft, The Netherlands \\ * Corresponding author (c.e.I.newton-1@tudelft.nl)
}

Submitted: 24 August 2021 | Accepted: 20 December 2021 | Published: 22 February 2022

\begin{abstract}
In Paraisópolis, a slum in São Paulo (Brazil) housing over 100.000 inhabitants, the Covid crisis seemed to have less of a death toll $(0,0217 \%)$ than in other areas of the city (an average of $0,0652 \%$ as of May 2020 ); or at least it did at first. The sense of community in the area is strong, leading to many community initiatives and organisations to rise to the challenge of combating the pandemic with little help from the authorities. The community's initial efficient response to the Covid crisis relied heavily on self-reliance and self-organization to mobilise common resources. Despite their later failure in containing the virus, the community's response to the pandemic is exemplary of a well-known phenomenon: how communities are able to mobilise the commons to create general welfare. The commons concept is used in this contribution to help us better understand slum governance and the power and limitations of community reliance. At the same time, we aim to refine our understanding of the commons as a contentious category rooted in agonistic relationships instead of the romanticised leftist social imaginary that views the commons as purely anti-capitalist. Thus, we explicitly argue for a view of the commons and commoning that transcends the narrow "Leftist imaginary" of the commons as egalitarian, inclusive, anti-capitalist, horizontal, and as expressions of sharing (and caring), and instead views the commons as embedded in everyday realities, where commoning practices emerge as practises that support the reproduction of (social) life.
\end{abstract}

\section{Keywords}

commons and commoning; community reliance; Covid-19 responses; grassroots and the state; informal settlements

\section{Issue}

This article is a part of the issue "The Politics and Aesthetics of the Urban Commons: Navigating the Gaze of the City, the State, the Market" edited by Peer Smets (Vrije Universiteit Amsterdam) and Louis Volont (Massachusetts Institute of Technology).

(C) 2022 by the author(s); licensee Cogitatio (Lisbon, Portugal). This article is licensed under a Creative Commons Attribution 4.0 International License (CC BY).

\section{Introduction}

Paraisópolis, the largest slum in São Paulo (Brazil), with over 100.000 residents crammed in approximately 118 hectares (IBGE, 2020), neighbours the elite neighbourhood of Morumbi. The harsh border between the two is often used to depict both the stark inequality and the close proximity of oppositional urban settings in megacities (see Figure 1). At the same time, it represents a complex web of interrelationships that include trade-offs between the slum and its surroundings, as well as the strategies used to negotiate with the state. Paraisópolis is almost embedded in Morumbi, an extremely wealthy neighbourhood in South West São Paulo. It is estimated that $60 \%$ to $80 \%$ of Paraisópolis inhabitants work in Morumbi (UN-Habitat, 2010) as domestic workers, nannies, security guards, construction workers, and store attendants, and a good number work in the thriving commercial activities of the slum itself.

In Paraisópolis, the Covid crisis initially appeared to have had a lower death toll $(0,021 \%)$ than in other parts of the city (an average of 0,065\%) in May 2020 (Instituto Polis, 2020). The area's strong sense of community and the interest of many NGOs and civil society organisations resulted in numerous community initiatives to tackle the pandemic. Self-reliance and self-organisation were critical in the community's rapid response to the Covid crisis, illustrating that "slums" are far more than their typical portrayal as the physical concentration of poverty (Szwarcwald et al., 2000; UN-Habitat, 2003), disease 
(Szwarcwald et al., 2000), informality (Roy, 2005), and illegality (Bromley, 1978; Mahmud, 2010), most often located in the fringes or the hazardous areas of megacities (Davis, 2006; UN-Habitat, 2003). However, as we have pointed out elsewhere (Rocco et al., 2021), the community's success in containing the pandemic was short-lived. An increase of almost $240 \%$ in morbidity rates in late 2020, from 21 deaths by 100.000 inhabitants in May 2020 to 54 deaths/100.000 inhabitants in August 2020, indicated the limits of community self-reliance within a metropolis and a country where the responses to the pandemic were almost unanimously recognised as botched. For public health doctor and researcher at the Polis Institute, Jorge Kayano, cites Mello (2020), "there was an exhaustion of community actions over the months[:] 'All the measures that have been adopted end up being exhausted over time because they are no longer able to contain the population inside their homes hoping to end the pandemic."

How can we understand the coordinated emergence of these rapid response actions while at the same time explaining the demise of these activities within several months? Numerous examples have shown that when the state is unable (or unwilling) to provide urban infrastructure and urban facilities, NGOs and citizen's organisations often step in to address the everyday needs through grassroots solutions (e.g., SPARC and Mahila Milan in Mumbai, The People's Homeless Federation in South-Africa, or the Orangi Pilot Project in Pakistan, just to name a few) and sometimes "appropriate significant parts of the means of governance" (Appadurai, 2002, p. 24). Is this what has happened in Paraisópolis? Are these initiatives illustrations of the insurgent struggle for true citizenship, which Holston (2009) terms "insurgent citizenship"? And, building on Miraftab (2009), is the rapid demise of the positive effects of these actions to be understood because of the co-optation and instrumentalisation of civil society and citizen participation by the state?

The argument we develop in this study is that, in order to understand how communities thrive or dwindle in the absence of citizens' rights and governmental intervention, the concept of a nested hierarchy of commons is extremely helpful. To substantiate this claim, we put forward two premises. First, we argue that communities are not islands: They exist in real political, economic, and physical settings and are influenced by what happens beyond their borders. And secondly, we challenge the concept of the commons as an anti-capitalist, anti-neoliberal category.

Thus, although we recognise the potential for insurgency in commoning activities and the role commoning may play in exploring an alternative to predatory neoliberal capitalism that extracts value from labour and land without redistributing the benefits of economic activity, we wish to challenge the idea that commons exist outside of the economic system surrounding them and rather than being purely insurgent against the market and the state, the commons exist in a complex web of continuous negotiation and trade-offs with them. In this sense, the concept of the commons is (a) still suitable to understand how slum dwellers can tackle their everyday challenges and (b) allows for a better understanding of how slums are governed, considering the existing complexities that characterise slums and their relation to the state and the market.

In other words, commoning in the slum is not (always) synonymous with anticapitalism, but it is rather a strategy that allows slum dwellers to bypass, challenge, and negotiate with the state and the market in order to get by and achieve their objectives. In this text, we examine how commoning can be used to accomplish multiple aims concurrently, as well as how it is entwined with formal and informal strategies and institutions, understood as the (formal and informal) norms that govern people's (and organisations') behaviour and actions. For Ostrom $(2008$, p. 24) "the term institutions refers to the rules that humans use when interacting within a wide variety of repetitive and structured situations" (see also North, 2005; Ostrom, 2005). Complementarity between formal and informal institutions is recognised, and informal institutions can be used to cover deficiencies in formal institutions (Bentkowska, 2021).

To substantiate these points, our third section discusses the slum as a condition of subaltern urbanism that we need to understand in its own merit, and as an integral part of our current urban reality, and not an anomaly. The following section then discusses the two views on the commons that are present in the contemporary debate, with, on the one hand, a political and critical scholarship that is mainly anti-capitalist and, on the other hand, a scholarship that works with the actual and existing commons, thus understanding commoning as a day-to-day strategy of negotiation.

In the fourth section, we then explore how both the commons and the slum interact in the case of Paraisópolis, and more precisely, the inhabitants' reaction to the challenges posed by the Covid-19 pandemic. The conclusion synthesises our findings and argues that a more practical operationalisation of the commons creates an opportunity for those who are now dispossessed to reclaim the city in their own terms.

\section{Methodology}

The article mainly draws on desk research to explain the planning context of Brazill and is supported by the ongoing research of the second author during the last 15 years and his years-long collaboration with community leaders and organisations in Paraisópolis. To understand the specific responses of the community to the Covid-19 pandemic, five interviews were conducted with two community leaders active in the area and with three municipal public servants. Interviews were conducted in Portuguese by the second author. Observations on the community's actions in dealing with the Covid crisis were 
discussed among the writers and between the second author and community leaders and government authorities. Furthermore, life stories have been collected from a number of inhabitants about their experiences during the Covid-19 pandemic (Rocco et al., 2021), these are used in this article to illustrate some of the points raised.

\section{Subaltern Urbanism and Citizen's Tactics}

As argued by scholars such as Roy (2011), Arabindoo (2011), and others, the portraying of "slums" and "megacities" within an "apocalyptic and dystopian narrative" impairs the daily life of their inhabitants to mere survival and strip their residents of their dignity, turning them into slumdogs and dispossessed victims. On the other hand, they are also critical of the non-nuanced romanticisation of slums as places of "creative self-organisation." Elsewhere (Rocco \& van Ballegooijen, 2018), we have argued that both victimisation and heroicisation of slum dwellers is unhelpful and fails to see them as political agents negotiating political and civil rights through an array of tactics and actions that frequently inhabit grey areas of formality and informality, as well as legality and illegality. As we point out there, Koolhaas' understanding of Lagos is exemplary in this regard, as he sees the city of Lagos at the forefront of globalising modernity, making the point that "Lagos is not catching up with us. Rather, we may be catching up with Lagos" (Koolhaas as cited in Baan \& van der Haak, 2002). Gandy (2005) and Fourchard (2011) rightfully point out that Koolhaas, in his admiration for informal, "spontaneous" organisation and "alternative systems," fails to understand that this informal organisation and alternative system is in itself a complex organisation, with internal hierarchies and power inequalities (Gandy, 2005, pp. 46-47) and that instead of a city that supposedly "escaped the colonial order," it is a city that "works especially for those who are able to extract money from the use of public space according to a web of client/patron relationships" (Fourchard, 2011, pp. 52-53). While informal urbanisation can certainly be understood from an insurgent perspective in which citizens fight for their right to have rights (Holston, 2011), it is also the material expression of exclusion from those rights. In summary, informal urbanisation is not an alternative to unimaginative planning and the tyrannies of capitalist production of space, but an integral element in the link between urbanisation and capitalism (Harvey, 2008).

Neither the dystopian images of the slum nor its over-romanticised depiction as creative, self-reliant, and heroic, come close to the everyday reality of life in what we could understand as contested urban conditions, whether they are located in the Global South or the Global North.

The acts of resistance performed in people's everyday lives in slums must also be understood through the material conditions and the very space they inhabit. Looking at the institutions (formal and informal) that shape the life in the slum and the tactics employed to negotiate with the state and the market is crucial to understand how the tactics of survival in the city alternatively normalise or challenge the relationship between citizens, the state and with neoliberal capitalism. Looking at space allows us to understand determinant elements that influence and shape those tactics, and often lead them to success or failure.

From the above, we derive two essential points. First, we need to understand the informal urban condition as relational, as an interaction between the existing material conditions and the daily systems of its inhabitants, made of the networks of social life and patterns of daily use of space, within and outside informal settlements themselves. This means that we move from an abstract and theoretical understanding of informality to an embedded and empirical one. Or as Arabindoo (2011, p. 638) argues: "Capturing the social, economic and cultural complexities of their everyday life is demanding as one needs to sift spatio-temporally through a layered multiplicity that is perhaps better unpacked empirically than theoretically." This also entails that we need to acknowledge the relation of the informal with its surroundings, spatially, socially, and politically.

Secondly, the material conditions of informality and related daily challenges are navigated by its inhabitants with flexibility and pragmatism. At the same time, these material conditions have a meaning at the political level, as they are the physical representation of the continuous challenging of the existing market regime and that regime's incapacity or unwillingness to ensure inhabitants their access to their citizen's positive rights (e.g., the right to decent housing, education, and healthcare, for example) and represent a challenge to the idea of democracy itself, as exclusion from the realm of rights for a portion of the population puts in check the notion of a liberal representative democracy.

We witness a similar pattern in the emerging research on the commons, where the commons are viewed as a practical means of governing the use of and access to a common pool resource on the one hand, and as an anti-capitalist political argument on the other. As Wagner (2012, p. 621) explains, "understanding commons as a social imaginary rather than a set of institutional property-rights arrangements makes it, in fact, more coherent as a social phenomenon and brings into play the role of imagination in creating alternatives to current power structures." This way of presenting the commons as an alternative to the current system is evident in the work of several scholars (Caffentzis, 2011; Caffentzis \& Federici, 2014; Chatterton \& Pusey, 2019; Cumbers, 2015; Dardot \& Laval, 2014; De Angelis, 2017a, 2017b; Gibson-Graham et al., 2016; Hardt \& Negri, 2009) and beautifully illustrated by this quote from Bollier and Helfrich (2019, p. 15), who highlight that "the elemental human impulse that we are born with-to help others, to improve existing practices-ripens into a stable social form with countless variations: a commons." 
Wagner (2012, p. 621) quotes Appadurai (1996):

The image, the imagined, the imaginary-these are all terms that direct us to something critical and new in global cultural processes: the imagination as a social practice....The imagination is now central to all forms of agency, is itself a social fact, and is the key component of the new global order.

The commons-as this imaginary-is thus helpful to explore alternatives to the capitalist hegemony, but if we want to better understand the actual commons, not as something outside of the current system, but as part of a complex web of relations with the state and the marker we need more than the social imaginary of the commons.

Bodirsky (2018) attempts to reconcile the "actually existing" practical common and the "Leftist imaginary" of the commons, which sees in the commons an instrument to overcome capitalism and achieve social justice. She recommends using the notion of property regimes to better comprehend the commons' relationship to the state and the market. This will be discussed in further detail in the following section.

\section{Commons: Social Engagement, Community Formation, and the Commons Exogenous Character}

Since Ostrom's (1990) pioneering work, progressive scholars and social movements critical of growth-based capitalism have viewed the concept of the commons as a possible alternative for the organization and structure of society (Caffentzis, 2011; Caffentzis \& Federici, 2014; Chatterton \& Pusey, 2019; Cumbers, 2015; De Angelis, 2017a, 2017b; Gibson-Graham et al., 2016) and increased attention has been paid to alternative and community economies.

\subsection{Social Engagement, Community Formation Polycentric Governance}

Whereas Ostrom analyses the commons alongside the state and the market, other authors have swiftly identified the commons as a potential counter-hegemonic force capable of undermining neoliberal capitalism in its current form. In today's struggle for a more just and fair future, scholars and activists are increasingly putting forward the concept of the (urban) commons as the to move away from our capitalist world (e.g., An Architektur, 2010; De Angelis, 2017a, 2017b; Marcuse, 2009; Stavrides, 2016).

A large and diverse coalition of urban citizens' movements is inspired and guided by the concept of the commons because it incorporates the various small struggles and oppositional forces that question neoliberal preponderance in a wide variety of ways, such as Cirugeda and Recetas Urbanas in Spain, or the reappropriation of abandoned theatres, railway infrastructure, or housing in Rome.
Just as the traditional approach popularised by Elinor Ostrom, this radical approach theorises the commons along three fundamental features: Commons are initiated by a group of people (a community), referred to as commoners, who design a set of rules and procedures in order to manage or to govern the shared use of a set of resources, which can be material (such as land and water) or intangible (such as knowledge or cultural practices).

The resurgence of the commons concept and its use from a critical theory perspective is helpful to understand the increase in bottom-up initiatives in which the participants are looking for new forms of engagement, solidarity, and responsibility over the resources they are interested in, while simultaneously trying to escape market logic. Just as in the more classical commons (many forests, lakes, common land, and cultural goods), or the commons associated with indigenous practices, the commoning of the modern (primarily urban) commons is not always performed by a homogeneous group. Fascinatingly, when we talk about online commons or knowledge commons, the commoners do not necessarily share the same physical space, as they find shared virtual spaces (see, e.g., Ertas et al., 2019). Today's critical scholarship studies the commons from an anti-capitalist perspective (e.g., Dardot, 2018) and too often presumes that self-governance occurs in a peaceful and cooperative culture within these movements (Deleixhe, 2018, p. 66). These illusions of harmony and uniformity are unhelpful in understanding urban commons' governance in today's unequal and divided societies. Ostrom (2010, p. 643) has argued that the capacity of people "to organise and solve social dilemmas," such as the under-provision of local public goods (e.g., health care during the Covid pandemic), is very much dependent on the specific context and should not be underestimated. She has also illustrated how the gradual and incremental learning processes take shape through experience, practice and trial and error. Although not everyone shares a similar understanding of the (severeness of the) situation, most commoners adopt norms of fairness and justice that allow for the legitimacy of those norms (Ostrom, 2010, p. 660).

Since the beginning, the acknowledgement of complexity, layering, and multiplicity has been present in Ostrom's work. Ostrom outlined eight principles that tended to be present in the successful commons she studied. Among these is the core notion of "nested enterprises" or "polycentric governance," a complex form of governance characterised by several decision-making centres with varying degrees of autonomy. In a recent contribution, Carlisle and Gruby (2019, p. 932) define polycentric governance systems as (a) "multiple, overlapping decision-making centres with some degree of autonomy" and (b) "choosing to act in ways that take account of others through processes of cooperation, competition, conflict, and conflict resolution."

Ostrom illustrated that successful commons often started in small-scale initiatives that, building on a growing network of organisations and individuals, gradu- 
ally tackled more significant problems using increasingly complex arrangements (Ostrom, 1990, pp. 187-189). The decisions taken by these initiatives are also partly influenced by the actions or the inaction of other actors in the system (Carlisle \& Gruby, 2019; Ostrom, 1990). Understanding commons governance as a polycentric system reveals the commons' exogenous nature (Ostrom, 1990, p. 190), demonstrating that the commons' success cannot be understood solely in terms of their internal consistency, but that their relationship to the larger system of the state and market in which they are embedded is also crucial (Smets \& Azarhoosh, 2019).

\subsection{Property Regimes and the "Actually Existing" Commons}

The problematic relationship between the state and the commons present in most current scholarship emphasises the citizens' lack of access or control of public goods. Scholars have argued to "extend the sphere of commons ecologies within society by turning public/private wealth into commons wealth" (De Angelis, 2017b, pp. 335-340) and, as such, take back control over the (common pool) resources. Again, this shows the longing for a better society, overcoming the current capitalist system. In reality, however, citizens are constantly moving between the different spheres created by state, market, and commons to provide for their livelihoods and reproduce social life. These three spheres are not in complete opposition (De Angelis, 2017b, pp. 332-336) and while we are aware of how the market uses commoning practices to its own benefit (e.g., volunteers in the organisation of large scale events), the opposite is also true. Commons use capitalist practices to sustain their projects or address (urgent) needs, as is illustrated in Paraisópolis' initiatives to face Covid-19 and discussed more extensively below. It thus makes good sense to follow Bodirsky's (2018, p. 122) suggestion to "define the commons as a (common pool) resource that can be managed in principle through various property regimes," thus acknowledging that commoning is "a set of practices that aim at the installation/defence of a common property regime over the commons." The common property regime (different from the public property regime or the private property regime) is characterised by an overlap of membership and ownership and is by definition not "open access" (Bodirsky, 2018, p. 127). The commons' reproduction depends on social relationships and agreements between commoners regarding the use, maintenance, and management of the (common pool) resource. The community that owns the resource regulates access to it, and membership does not guarantee equitable access.

In conclusion, we move away from the utopian imaginary of the commons and stress that "actually existing commons" are:

1. made out of a (common pool) resource (material or intangible);
2. managed under a common property regime (characterised by an overlap of ownership and membership) that is designed by a group of people (a community), referred to as commoners;

3. characterised by sharing relations that are intertwined with capitalist practices;

4. not necessarily motivated by political or ideological opposition to capitalism or the state.

When we look at the case of Paraisópolis, we might even claim that it is precisely the relation with the state and the market that allows the common to sustain itself over time. This is illustrated in the next section.

\section{Paraisópolis as the Polycentric Governance of Nested Commons}

\subsection{Paraisópolis}

Paraisópolis is a neighbourhood in the southwest of São Paulo. Although numbers are disputed, it is said to be the biggest slum in São Paulo. The 2010 Brazilian census counted roughly 43.000 inhabitants (IBGE, 2020), but it is believed the area had around 100.000 inhabitants in $0,8 \mathrm{~km}^{2}$ in 2020, making it the densest residential neighbourhood in Brazil (Oliveira, 2016). Although Paraisópolis is widely recognised as a favela (slum) and has all the attributes of one, its citizens never refer to it as such, but prefer to call it "the community." Only $25 \%$ of its inhabitants have access to sanitation, half the streets are unpaved, and $60 \%$ of households tap into the energy grid illegally (Oliveira, 2016). Although more than $90 \%$ of households have access to running water, water provision is defective and irregular.

Most importantly, the history of Paraisópolis is intimately connected to the notion of accumulation by dispossession (Harvey, 2012, 2014). The settlement was created in 1921 by subdividing a former coffee farm into 2,200 plots of $10 \mathrm{~m} \times 50 \mathrm{~m}$ and laying out regular 10-metre-wide roadways on irregular terrain, destined for the construction of high-end residences.

The development flopped, partly because of the poor accessibility of the area. The plots were unlawfully occupied in the 1950s by immigrants from the Brazilian Northeast drawn to the city's increasing industrialisation. Attracted by its semi-rural green hills, wealthy São Paulo elites settled into Morumbi, offering impoverished migrants work in construction and as domestic helpers. Because of public negligence and a lack of efficient housing policy, poor migrants resorted to "help themselves" by building temporary wooden shacks that quickly became permanent brick buildings of poor quality, without sewerage, and inconsistent and illegal access to water and electricity; 20,000 people lived illegally in the area in 1970 (Vilicic et al., 2009).

In the early 1980s, with Brazil still under military rule, the controversial military-appointed mayor Paulo Maluf tried to remove the slum by proposing the construction 
of an avenue through the area. Several mayors use this well-documented strategy to get rid of what they see as "eyesores" in the city. Slum dwellers used to have next to no protection against evictions, which were often carried out overnight and involved police violence. This was fuelled by intense land valorisation in the area, with the construction of luxury walled condominiums, and great interest by real estate developers to get rid of the slum and develop the area. It is possible to imagine that some of the original plot owners, who by now are resigned to having lost their land to illegal occupation, would also benefit. The project failed thanks to fierce resistance from the community and the action of comunidades eclesiais de base, i.e., civil rights groups supported by the more progressive sections of the Catholic Church, animated by teologia da libertação (liberation theology), a Christian theological approach emphasising the liberation of the oppressed that took root in Latin America from the mid-1960s.

Local governments would refuse to provide public services, stating it was unconstitutional to do so until the land ownership issue was resolved. In brief, illegality meant the state did not act. The military dictatorship did not regard the poor, predominantly black and mixedrace residents of Paraisópolis as valid civil rights holders. The country's democratisation in 1986 and the introduction of a new progressive constitution in 1988 eventually brought change.

In 2003, a process of urbanisation and regularisation of land ownership began, similar to the process that took place in the former favela of Heliópolis. This process of land regularisation was based on one of the instruments proposed by the City Statute, a federal bill signed in 2001 containing one of the most progressive and ambitious urban development guidelines the country had seen.

In 2007, the State of Sao Paulo developed the Legal City Program to assist municipalities in regularising homes located on illegally occupied land (SEHAB, 2007). This story tells us of a resource (land) that is made "common" through the actions of a multitude of uncoordinated actors occupying underutilised land illegally, and progressively establishing both practical and moral ownership, which is ensured through the sheer number of occupations, their newly acquired notion of "citizens' rights" (especially after the Brazilian Constitution of 1988, but before that through the actions of the Church and community leaderships) and later through legal support via progressive legislation. This practical and moral ownership is built over time, in a very complex fashion, and is reinforced by various episodes of collective resistance to eviction and internal conflict. Other actors also play a role in negotiating ownership, notably organised crime, the action of evangelical leaders and the actions of a number of NGOs that support the predicaments of the inhabitants. But, simultaneously with this "commoning" process, there is a juxtaposing formation of a land and housing market in the slum, with houses and house extensions being rented to newcomers. We have no studies about the real estate market in Paraisópolis, nor the number of rented units to owner's occupied dwellings, but research conducted elsewhere in São Paulo (Baltrusis, 2004) indicates the existence of a vigorous market within the slum, with the action of "slum lords" (owners of multiple houses that make a living from renting them), possibly connected to drug traffic. In short, Paraisopolis is a paradoxical example of commoning that includes market elements and which has been the object of intense state action in the last 40 years.

\subsection{Paraisópolis' Nested Commons}

The impact of the Covid pandemic has been the hardest for the already more vulnerable groups in society, with slum dwellers disproportionately affected (Tampe, 2020). While governments worldwide tried to address the pandemic by imposing lock-downs and trying to back up their health care systems, slum areas and other already left behind places tried to address the emergency to the best of their abilities, sometimes without the support of the state. In what follows, we will illustrate how the nested commons in Paraisópolis evolved and shaped slum governance through time, with the Covid response being utilised to highlight specific features. More precisely, we will dissect three aspects that substantiate our thesis that the concept of a nested hierarchy of commons is particularly useful in understanding how communities survive or perish in the absence of citizens' rights and state action.

\subsection{Property Regimes in Paraisópolis}

Since the appearance of the favela in the 1950s, the inhabitants have tackled the social dilemmas they were faced both individually and collectively and found their force in numbers. The illegal utilisation of electricity and water infrastructure was a first step toward addressing a deficit of public goods provided by the state.

When the Covid-19 pandemic hit the favela in April 2020, young community leaders in Paraisópolis banded together to battle the new challenge. In the months leading up to the first local Covid cases, the community realised that if they were to survive the pandemic, they needed to act to survive the epidemic, because the government's intervention would likely be too late. Givanildo, a 20-year old community leader, reminds us: "As they [the government] don't do anything for us, we have decided to help ourselves" (Rocco et al., 2021). Local organisations mobilised the community and investigated how existing facilities and new initiatives could mitigate the situation. The community hired medical staff and ambulances on its own, making them available 24 hours a day to the local people. Through a crowdfunding campaign, local businesses were encouraged to give free meals and personal hygiene supplies.

Community leaders recruited over 600 volunteers to serve as "street presidents" and trained over 240 
individuals to administer first aid. The street presidents' system was novel. These volunteers were assigned responsibility for an entire street (approximately 50 families); they not only provided direct information to residents about the disease and informed them about practicalities (use of masks, use of public transportation, curfew hours), but they also had their finger on the pulse of the street and could react when residents were in need or became ill. Those educated in first aid helped in the two schools that operated as quarantine and treatment centres. The ambulance service and the treatment facilities can be understood as common-pool resources, for which yet another regime was established, providing the most open access to it as possible. Next to these very tangible resources, knowledge sharing is another common pool resource that allowed residents to stay informed, especially in the first months, when the disease was still alien to everyone and information and best-practices tended to change over time, and to take the necessary measures to protect themselves.

As we have argued, this "commons" creation was both typical to the favela and confined to it. Such mobilisation was not seen in other parts of the formal city, where citizens relied exclusively on the public response by authorities. Despite initial successes in keeping the number of infections and deaths very low in relation to the rest of the city, and especially in relation to the wealthy neighbourhood surrounding the favela (Mello, 2020; Rocco et al., 2021), the lack of support by local authorities meant that the resources mobilised by the community were not enough to prevent further infections and deaths later in the pandemic, on par with what happened in the rest of the city. Notwithstanding the late failure to combat the pandemic and the apparent limitations to community action, the fact that such community action existed at all, while other parts of the city did not self-organise, is notable and tells us about the specific conditions that led the community to develop a sense of purpose and to ensure the commons created by all of them (sometimes individually and sometimes in groups) would be preserved.

\subsection{Public Space Pace as Common and Space as the Cradle for Nested Commons}

Addressing social concerns and safeguarding their common space were significant motivators for the formation of resident organisations and associations in Paraisópolis, as well as for the emergence of local service providers and commercial enterprises. Initially, the resident associations addressed concerns such as education, sanitation, and healthcare (Bento \& Couto, 2021). Mion (2018, p. 103) considers that the favela functioned as an autonomous system, and a whole structure of associations has developed to organise access to public goods the local government failed to provide.

The complex governance of the slum is deeply interconnected with its spatial configuration. The eminently distinct space of the favela, with its well-defined main streets but an impossibly complicated network of alleyways, culs-de-sac, and narrow corridors between houses, offers a space of exception from the well-lit streets in the formal city. There is a situation of separation from the formal city, with clearly demarcated limits between favela and the formal neighbourhoods around it, and this separation offers protection from elements exogenous to the favela. These spaces house a multitude of informal, often illegal, and occasionally criminal activities, protected from the prying eyes of the authorities. The way store owners' associations work together with cultural and sports organisations and criminal organisations is well illustrated in Paraisópolis by the weekly funk dance events the favela hosts. Funk dance parties are prevalent events in Brazil's favelas, attracting thousands of participants. Parties in Paraisópolis attract more than 5.000 people to dance and party through the night in the streets. These parties are organised by the shop owner's association and are confined to four streets in the slum, prompting inhabitants from these streets to move away, bothered by the noise, leaving space for more commercial activities, also influenced by criminal gangs (Machado, 2019). Since 2003, the presence of these gangs has been prominent in Paraisópolis, particularly the criminal drug gang Primeiro Comando da Capital (PCC).

The events are good for the shop owners' business and lucrative for the gangs. The space of the favela is claimed by the partygoers during these nights, while during the day, they are used by the residents of the favelas. They are the same spaces where the street presidents and volunteers informed community members about the pandemic. Thus, different subgroups of the community make use of the same spatial resource in very different ways, taking advantage of the ghettoised spaces of the favela. As Stavrides (2016, p. 260) argues, "space matters because it is not an inert container of social life but an integral part of its manifestations and its events. Space gives form to encounters because it is a structured system of relations." However, through the different ways of appropriation, the public space also enforces a certain perception of what the favela is. Space, and especially public space, is predominantly perceived in the form of stereotyped images that circulate through the different media channels and contrast to the dominant culture of a society (Stavrides, 2016, p. 185). This idea is illustrated in the numerous pictures existing of the juxtaposition of Paraisópolis and its wealthy neighbour Morumbi (see Figure 1) and the "strangeness" of cultural manifestations of the favela to the inhabitants of the formal city. More interestingly, Stavrides (2016, p. 262, emphasis added) argues that "common spaces challenge situated identities as well as the fixity of boundaries of any preexisting community from which "individuals draw their own self-images." Two consequences are derived from this and are visible in Paraisópolis. First, the claiming of the public spaces by the street presidents and volunteers 


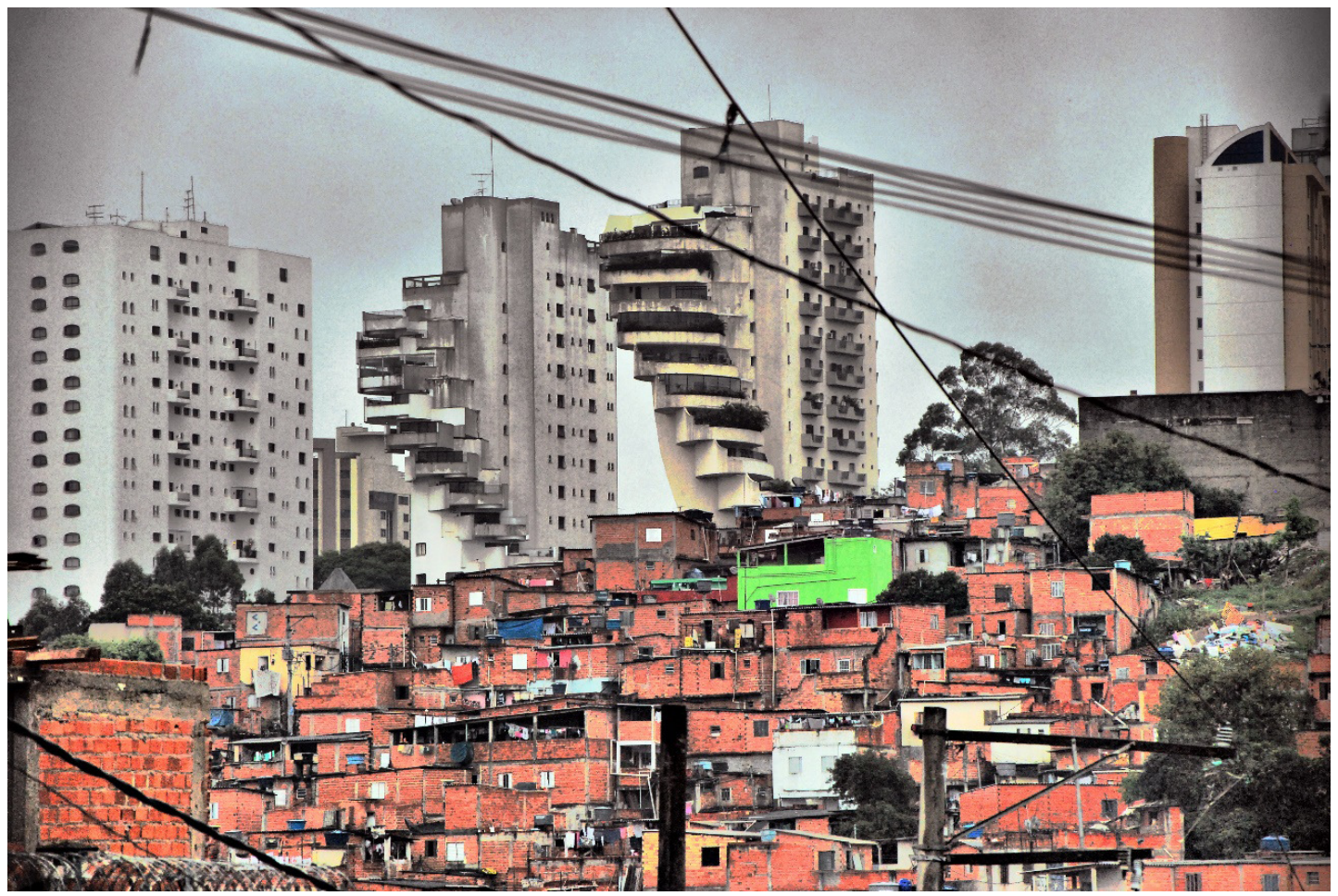

Figure 1. Paraisópolis and Morumbi (picture by Roberto Rocco).

not only turn the public spaces into common spaces, their presence in the street and the representations of the street itself in this way are challenging the dominant image of the slum to the outside world. It shows that Paraisópolis is a community in motion, constantly reinventing itself, its organisations and spaces. It is, as Stavrides (20156, p. 125) would call it, "a community-inthe-making."

Secondly, the spatial representation of the slum and its actual physical condition serves as a nurturing condition for the other commons. The urban context and spatial conditions of Paraisópolis have been, and still are, what brings people together, what nurtures the establishment and emergence of other types of commons. During the Covid pandemic, the spatial constraints of small houses, as well as the overcrowding caused by people's incapacity to go out to work promoted the emergence of new commons, such as people temporarily migrating out of the slum and sharing housing to alleviate overpopulation (and the tension that comes with it).

\subsection{Paraisópolis' Actually Existing Commons}

In the 1980s, the government's attempt to clear the slum was halted because the community organised strong resistance with the help of human rights organisations and the church. These prior encounters with social difficulties fostered self-organisation. Several distinct favelado organisations are active in Paraisópolis. Since 1983, the Union of Inhabitants of the Favela of Paraisópolis (or Union) has defended the residents' concerns. The Multi-Stakeholder Forum was established in
1994 to better integrate social programmes in the favela, and the Steering Committee for Paraisópolis was formed in 2004 to monitor the slum's upgrading, particularly the multi-year efforts of SEHAB, the local housing authority.

The collaborations of these institutes illustrate that it is an illusion to look at the slum as "autonomous" or separated from the surrounding "formal" city. The specific physical conditions of the slum allow for a "border" condition, in which the "common spaces" are recognisable in opposition to the well-organised city around it, with its demarcated plots, streets and public spaces, its sewerage systems, and its well-controlled utilities, measured and billed. Over time, this aggregation of initiatives and associations developed into a dense network of overlapping decision-making centres with varying degrees of autonomy that choose to work cooperatively or competitively to facilitate the use and management of (common pool) resources, especially space, but also utilities, public transport, education and health provision. At various points in time, agreements with NGOs, organisations, and the state were sought in order to facilitate access to and use of a particular resource. These (temporary) collaborations or coalitions are reflected in the emergence of favelado organisations mentioned above.

Several initiatives illustrate the intense relationship between the state, the market, and the common during the pandemic. Community kitchens were created to distribute free meals for those who could not afford to buy food. The recently established G10 group in the ten biggest favelas in Brazil was an initiative by community leaders of these favelas triggered by the Covid pandemic. It aims to bring access to credit to the favela, to stimulate 
private initiatives and SME's. Brazilian favelas have a GDP exceeding that of several large Latin American cities (Boehm, 2020).

The community is thus constantly organising and re-organising itself, testing different ways to organise and govern the slum. We argue that the shared spaces and the border conditions with the formal city are essential. These spaces feed and nurture the other commons. Sennett (2008, p. 237) describes how the improvised appropriation of the street by hawkers, shopkeepers, and tenants illustrates Rudofsky's (1964) point that it is precisely this improvisation of the street that which "attaches people to their communities." The appropriation of the slums' shared spaces are acts of commoning, and as De Angelis (2017b, pp. 90-98) stressed: "Through commoning, subjects create conditions of resilience and selforganisation and may develop from grassroots into more all-encompassing systems." The shared spaces of the slum also show how the state and market are not alien from the common. The three are linked and work together.

\section{Conclusion}

This article contributes to the increasing body of knowledge about the commons by providing a way to break free from the paralysing constraints of a Left-wing, utopian anti-capitalist paradigm that romanticises the commons and the commoners. We believe this romanticisation is not helpful when reimagining alternatives to neoliberalism. A more practical operationalisation of the commons opens up opportunities for the reclamation of the city by those who are currently dispossessed. It helps us understand how vulnerable citizens negotiate their daily existences with the space they occupy, the formal and informal institutions, the state, and the market.

In Paraisópolis, numerous practices illustrate precisely how, through the everyday practices, navigating the space of the market, the state, and the common, people are reclaiming the city.

They navigate the space of the market by starting businesses or by their jobs outside of the slum. Most residents of slum areas are faced with considerable commuting time to and from work, sometimes taking up to four hours. Most of the residents of Paraisópolis work in the adjacent elite neighbourhood of Morumbi (UN-Habitat, 2010). Their work in Morumbi is their essential source of income and their labour is needed in Morumbi, realising a mutual dependency between the two areas, illustrating that the residents of Paraisópolis are an integral part of the city.

They also navigate the spaces created by the state, by self-organising education or, during the Covid pandemic, medical care. Their ability to navigate these spaces on a daily basis is nurtured in the realm of the commons, which has evolved in Paraisópolis over time to become a nested hierarchy of multiple, overlapping decisionmaking centres, ranging from criminal organisations such as the PCC to SME organisations or collaborative struc- tures between the community and the state, such as the Steering Committee for Paraisópolis. Each of these organisations has a different degree of autonomy, and their engagement with other organisations can be based on cooperation (such as the SME organisations or the Committee, and even between the shopkeeper's organisation and the P(C), but at times will be characterised by competition (e.g., the control over accessing the electricity grid) or even conflict.

The case of Paraisópolis demonstrates that citizens' managing of the commons is capable of ensuring its inhabitants' livelihoods, reproducing social life, and that citizens have the practical resources (space) and the moral stand to procure the resources (such as electricity and running water) and support structures (education or health care during the pandemic) that the state is so reluctant to provide, either by negotiating with the state or with the market and sometimes with both. In other words, The web of nested commons in Paraisópolis is embedded in a relationship with the state and the market, whether through dialogue or struggle for access to resources such as land, running water, or electricity, or for the appointment of a private ambulance service to transport the sick to the hospital. Hence, the actual common is inextricably linked to capitalist activities, from procuring external services to conducting economic transactions.

A representative democracy cannot function if significant segments of the population are routinely denied access to the realm of rights. At least in Brazil, this is inextricably linked to market inclusion, and so exclusion from the market entails inevitable exclusion from the sphere of rights. The Workers Party sought to address this distortion; nevertheless, its accomplishments are being undone by the Bolsonaro regime. In Paraisópolis, the residents gradually reclaim their rights, and they do so by engaging in mutually dependent relationships with their neighbours, by bringing market practices within the slum and creating a vibrant and thriving economy. They do it by taking over some responsibilities from the state in view of its indifference or hostility. What has nurtured these capabilities is the presence of a number of nested commons that emerged gradually since the favela was established. These nested commons are thus the leverage that allowed the residents in Paraisópolis to reclaim the city.

\section{Conflict of Interests}

The authors declare no conflict of interests.

\section{References}

An Architektur. (2010). On the commons: A public interview with Massimo De Angelis and Stavros Stavrides. e-flux, 17. https://www.e-flux.com/journal/17/ 67351/on-the-commons-a-public-interview-withmassimo-de-angelis-and-stavros-stavrides 
Appadurai, A. (1996). Modernity at large: Cultural dimensions of globalization (Vol. 1). University of Minnesota Press.

Appadurai, A. (2002). Deep democracy: Urban governmentality and the horizon of politics. Public Culture, 14(1), 21-47.

Arabindoo, P. (2011). Rhetoric of the "slum." City, 15(6), 636-646. https://doi.org/10.1080/13604813. 2011.609002

Baan, S. (Producer), \& van der Haak, B. (Director). (2002). Lagos/Koolhaas [Documentary]. Icarus Films.

Baltrusis, N. (2004). O mercado imobiliário informal em favelas na região metropolitana de São Paulo. O caso de Guarulhos [The informal real estate market in slums in the metropolitan region of São Paulo. The case of Guarulhos]. Cadernos da Metropole, 11(1), 107-136.

Bentkowska, K. (2021). Formal and informal institutions' changes in the sharing economy development. European Research Studies Journal, 24(1), 362-375. https://doi.org/10.35808/ersj/2047

Bento, F., \& Couto, K. C. (2021). A behavioral perspective on community resilience during the Covid-19 pandemic: The case of Paraisópolis in São Paulo, Brazil. Sustainability (Switzerland), 13(3), 1-18. https://doi. org/10.3390/su13031447

Bodirsky, K. (2018). The commons, property, and ownership. Suggestions for further discussion. Focaal: Journal of Global and Historical Anthropology, 81, 121-130. https://doi.org/10.3167/fcl.2018.810109

Boehm, C. (2020, October 14). Moradores de favelas movimentam $\mathrm{R} \$ 119,8$ bilhões por ano. Agência Brasil. https://agenciabrasil.ebc.com.br/geral/ noticia/2020-01/moradores-de-favelasmovimentam-r-1198-bilhoes-por-ano

Bollier, D., \& Helfrich, S. (2019). Free, fair, and alive: The insurgent power of the commons. New Society Publishers.

Bromley, R. (1978). Introduction-The urban informal sector: Why is it worth discussing? World Development, 6(9), 1033-1039. https://doi.org/https://doi. org/10.1016/0305-750X(78)90061-X

Caffentzis, G. (2011). The future of "the commons": Neoliberalism's "plan B" or the original disaccumulation of capital? New Formations, 69(69), 23-41. https://doi.org/10.3898/newf.69.01.2010

Caffentzis, G., \& Federici, S. (2014). Commons against and beyond capitalism. Community Development Journal, 49(Suppl. 1). https://doi.org/10.1093/cdj/ bsu006

Carlisle, K., \& Gruby, R. L. (2019). Polycentric systems of governance: A theoretical model for the commons. Policy Studies Journal, 47(4), 921-946. https://doi. org/10.1111/psj.12212

Chatterton, P., \& Pusey, A. (2019). Beyond capitalist enclosure, commodification and alienation: Postcapitalist praxis as commons, social production and useful doing. Progress in Human Geography, 44(1),
27-48. https://doi.org/10.1177/0309132518821173

Cumbers, A. (2015). Constructing a global commons in, against and beyond the state. Space and Polity, 19(1), 62-75. https://doi.org/10.1080/13562576.2014. 995465

Dardot, P. (2018). What democracy for the global commons? In S. Cogolati \& J. Wouters (Eds.), The commons and a new global governance (pp. 20-36). Edward Elgar Publishing. https://doi.org/10.4337/ 9781788118514.00010

Dardot, P., \& Laval, C. (2014). Commun. Essai sur la révolution au XXIe siècle [Common. An essay on revolution in the 21st century]. Le Découverte.

Davis, M. (2006). Planet of slums. Verso.

De Angelis, M. (2017a). Grounding social revolution: Elements for a systems theory of commoning. Zed Books.

De Angelis, M. (2017b). Omnia sunt communia: On the commons and the transformation to postcapitalism. Zed Books.

Deleixhe, M. (2018). Conflicts in common(s)? Radical democracy and the governance of the commons. Thesis Eleven, 144(1), 59-79. https://doi.org/10.1177/ 0725513618756089

Ertas, H., Pak, B., \& Newton, C. (2019). An operational framework for an online community based on the commons, dissensus and shared knowledge. Postdigital Science and Education, 2. https://doi.org/ 10.1007/s42438-019-00067-6

Fourchard, L. (2011). Lagos, Koolhaas and partisan politics in Nigeria. International Journal of Urban and Regional Research, 35(1), 40-56. https://doi.org/ 10.1111/j.1468-2427.2010.00938.x

Gandy, M. (2005). Learning from Lagos. New Left Review, 33, 37-52.

Gibson-Graham, J. K., Cameron, J., \& Healy, S. (2016). Commoning as a postcapitalist politics. In A. Amin \& P. Howell (Eds.), Releasing the commons: Rethinking the futures of the commons (pp. 192-212). Routledge. https://doi.org/10.4324/9781315673172-12

Hardt, M., \& Negri, A. (2009). Commonwealth. Harvard University Press.

Harvey, D. (2008). The right to the city. New Left Review, 53, 23-40. https://newleftreview.org/issues/ii53/ articles/david-harvey-the-right-to-the-city

Harvey, D. (2012). Rebel cities: From the right to the city to the urban revolution. Verso.

Harvey, D. (2014). Seventeen contradictions and the end of capitalism. Oxford University Press. http:// kehuelga.net/diario/IMG/pdf/harvey17 contradictions.pdf

Holston, J. (2009). Insurgent citizenship: Disjunctions of democracy and modernity in Brazil. Princeton University Press.

Holston, J. (2011). Contesting privilege with right: The transformation of differentiated citizenship in Brazil. Citizenship Studies, 15(1), 335-352.

IBGE. (2020). Panorama paraisópolis. https://cidades. ibge.gov.br/brasil/mg/paraisopolis/panorama 
Instituto Polis. (2020). Paraisópolis tem melhor controle da pandemia que o município de São Paulo [Paraisópolis has better control of the pandemic than the municipality of São Paulo]. https://polis.org.br/ noticias/paraisopolis

Machado, L. (2019, December 1). O que é o "Baile da 17"? Pancadão em Paraisópolis onde 9 jovens morreram pisoteados [What is the "Baile da 17"? Beating in Paraisópolis where 9 youths were trampled to death]. BBC News Brasil. https://www.bbc.com/ portuguese/brasil-50624480

Mahmud, T. (2010). "Surplus humanity" and margins of legality: Slums, slumdogs, and accumulation by dispossession. Chapman Law Review, 14(1), 10-26.

Marcuse, P. (2009). From critical urban theory to the right to the city. City: Analysis of Urban Trends, Culture, Theory, Policy, Action, 13(2), 185-197. http://www.informaworld.com/10.1080/13604810 902982177

Mello, D. (2020, September 9). Taxa de mortalidade por Covid-19 em Paraisópolis aumenta 240\% [Covid-19 mortality rate in Paraisópolis rises 240\%]. Agencia Brasil. https://agenciabrasil.ebc.com.br/saude/ noticia/2020-09/taxa-de-mortalidade-por-covid-19em-paraisopolis-aumenta-240-0

Mion, V. (2018). Undergrowth urbanism: The role of usergenerated practices in the informal city. A methodology for analysis and intervention based on the case study of Paraisópolis in São Paulo. In A. Petrillo \& P. Bellaviti (Eds.), Sustainable urban development and globalization (pp. 99-116). Springer.

Miraftab, F. (2009). Insurgent planning: Situating radical planning in the Global South. Planning Theory, 8(1), 32-50. https://doi.org/10.1177/1473095208099297

North, D. C. (2005). Understanding the process of institutional change. Princeton University Press.

Oliveira, N. d. (2016, March 16). IBGE divulga grade estatística e atlas digital do Brasil [IBGE publishes statistical matrix and digital atlas of Brazil]. Agência Brasil. https://agenciabrasil.ebc.com.br/economia/ noticia/2016-03/ibge-divulga-grade-estatistica-eatlas-digital-do-brasil

Ostrom, E. (1990). Governing the commons. The evolution of institutions for collective action. Cambridge University Press.

Ostrom, E. (2005) Understanding institutional diversity. Princeton University Press.

Ostrom, E. (2008). Institutions and the environment. Economic Affairs, 28(3), 24-31. https://doi.org/10.1111/ j.1468-0270.2008.00840.x

Ostrom, E. (2010). Beyond markets and states: Polycentric governance of complex economic systems. American Economic Review, 100(3), 641-672. https://doi. org/10.1257/aer.100.3.641

Rocco, R., José, B. K., Carvalho, H., \& Royer, L. (2021).
The impact of socio-spatial inequity: Covid-19 in São Paulo. In B. Doucet, R. van Melik, \& P. Filion (Eds.), Global reflections on Covid-19 and urban inequalities (Vol. 1, pp. 129-140). Bristol University Press.

Rocco, R., \& van Ballegooijen, J. (Eds.). (2018). The Routledge handbook on informal urbanisation. Routledge.

Roy, A. (2005). Urban informality: Toward an epistemology of planning. Journal of the American Planning Association, 71(2), 147-158.

Roy, A. (2011). Slumdog cities: Rethinking subaltern urbanism. International Journal of Urban and Regional Research, 35(2), 223-238. https://doi.org/ 10.1111/j.1468-2427.2011.01051.x

Rudofsky, B. (1964). Architecture without architects: An introduction to nonpedigreed architecture. The Museum of Modern Art.

SEHAB. (2007). Cidade legal [Legal city]. http://www. habitacao.sp.gov.br/icone/detalhe.aspx?ld=29

Sennett, R. (2008). The craftsman. Yale University Press.

Smets, P., \& Azarhoosh, F. (2019). Real estate as a commons: Collaboration between communities, housing corporations, and the local government in Amsterdam East. In B. Tejerina, C. M. de Almeida, \& I. Perugorría (Eds.), Sharing society: The impact of collaborative collective actions in the transformation of contemporary societies. (pp. 281-296). Servicio Editorial.

Stavrides, S. (2016). Common space: The city as commons (Vol. 70). Zed Books. https://doi.org/10.5040/ 9781350219267

Szwarcwald, C. L., Bastos, F. I., Barcellos, C., Pina, M. d. F., \& Esteves, M. A. P. (2000). Health conditions and residential concentration of poverty: A study in Rio de Janeiro, Brazil. Journal of Epidemiology and Community Health, 54(7), 530-536.

Tampe, T. (2020). Potential impacts of Covid-19 in urban slums: Addressing challenges to protect the world's most vulnerable. Cities \& Health. Advance online publication. https://doi.org/10.1080/23748834. 2020.1791443

UN-Habitat. (2003). The challenge of slums-Global report on human settlements 2003. https://mirror. unhabitat.org/content. asp?typeid $=19 \&$ catid $=555 \&$ cid $=5373$

UN-Habitat. (2010). São Paulo: A tale of two cities.

Vilicic, F., Bergamo, G., de Salvo, M. P., \& Duarte, S. (2009, September 18). Violencia em Paraisopolis, a segunda maior favela da cidade [Violence in Paraisopolis, the city's second largest favela]. Veja São Paulo. https://vejasp.abril.com.br/cidades/violencia-emparaisopolis-segunda-maior-favela-da-cidade

Wagner, J. R. (2012). Water and the commons imaginary. Current Anthropology, 53(5), 617-641. https:// doi.org/10.1086/667622 


\section{About the Authors}

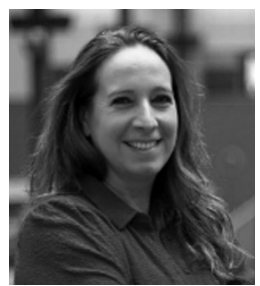

Caroline Newton is an urban planner, an architect, and a political scientist. Her work focuses on the social and political dimensions of design. Caroline's research focuses on (informal) housing and participatory upgrading, post-colonial architecture and planning, and the methodological and pedagogical challenges of designerly knowledge production. Caroline advocates for advocacy in planning and spatial practises. Strategic planning, she argues, could be seen as an act of resistance, enabling alternative spatial possibilities and imaginations.

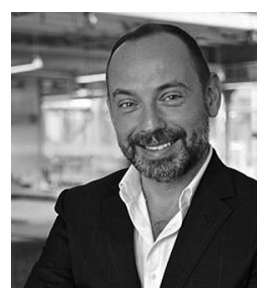

Roberto Rocco is an associate professor of spatial planning and strategy at TU Delft. Roberto is trained as an architect and spatial planner with a master's in planning from the University of São Paulo and a PhD from TU Delft. Roberto specialises in governance for the built environment and social sustainability, as well as issues of governance in regional planning and design. Roberto produces research on how informal institutions influence and shape planning at the local level. He is a consultant for the Union for the Mediterranean and has recently drafted the UfM Action Plan for Sustainable Urbanisation 2040 (https://ufmsecretariat.org/urban-agenda). 